\title{
Effect of a low dose of intraduodenal fat on satiety in humans: studies using the type A cholecystokinin receptor antagonist loxiglumide
}

\author{
R J Lieverse, J B M J Jansen, A A M Masclee, L C Rovati, C B H W Lamers
}

Abstract

Satiation, the process that brings eating to an end, and satiety, the state of inhibition over further eating, may be influenced by cholecystokinin (CCK). In animal and human studies, it has been shown that infusion of exogenous CCK decreases food intake, but the doses given may well have led to supraphysiological plasma concentrations. This study was done to discover if a low dose of intraduodenal fat releasing physiological amounts of endogenous cholecystokinin exerts satiation or satiety effects, or both and if these effects could be inhibited by the CCK receptor antagonist loxiglumide. In 10 healthy lean volunteers (5 F, $5 \mathrm{M}$, mean age 26$)$ three tests were performed in a randomised blind fashion. Intralipid $20 \%(6 \mathrm{~g} / \mathrm{h})$ (experiments $A$ and $C$ ) or saline (experiment B) were given intraduodenally from 1030 until 1300 . The subjects received saline (experiments $A$ and $B$ ) or loxiglumide (experiment $\mathrm{C}$ ) a specific CCKreceptor antagonist $(10 \mathrm{mg} / \mathrm{kg} / \mathrm{h})$ intravenously from 0930 until 1300. At 1200 a meal was served. At regular time intervals hunger feelings were measured using visual analogue scales and food selection lists and plasma CCK was measured by radioimmunoassay. Food intake (mean (SEM)) during intraduodenal fat $(206(35) \mathrm{g})$ was lower than in the control study (269 (37) $\mathrm{g}, \mathrm{p}=0.09)$. Loxiglumide largely prevented the inhibitory effect of intraduodenal fat on food intake $(245$ (30) g). From 1030 until the meal at 1200 there was a significant satiating effect of intraduodenal fat compared with the control and loxiglumide experiments according to the food selection lists, which was because of the satiating effect for the fat rich items $(p<0.05)$. Also feelings of fullness were significantly higher during intraduodenal fat than in the control or loxiglumide experiments $(p<0.05)$. During intraduodenal fat there was a significant increase of plasma CCK from 2.4 $(0.3)$ to $4.8(0.4) \mathrm{pM}(\mathrm{p}<0.001)$. Loxiglumide led to an exaggerated $\mathrm{CCK}$ release to a peak concentration of $16(2.4) \mathrm{pM}$ before the meal. This study shows that in humans low dose intraduodenal fat increases satiety and satiation, mainly through the effect of CCK.

(Gut 1994; 35: 501-505)

Rotta Laboratories, Monza, Italy

L C Rovati

Correspondence to: Dr R J Lieverse, Department of GastroenterologyHepatology, University Hospital of Leiden, Building 1, C4-P, PO Box 9600, 2300 RC Leiden, The Netherlands.

Accepted for publication 9 August 1993

After eating a certain amount of food, further ingestion is stopped. This process is called satiation whereas satiety can be considered as the state of inhibition over further eating. ${ }^{1}$ Many authors, however, use the term satiety when both processes are meant. Different factors may combine to cause this satiation mechanism, such as the release of hormones from the digestive tract, absorption of nutrients but also sensory and cognitive influences. ${ }^{2}$ Cholecystokinin (CCK), a hormone released from the proximal small bowel after contact with digested fat and protein but not carbohydrate ${ }^{3}$ is a candidate satiation hormone. From 1973 a number of reports have shown that CCK induces satiation in several species. ${ }^{429}$ Also in human studies it has been shown that infusion of exogenous CCK decreases food intake..$^{30-33}$ In these human experiments, however, CCK concentrations were not measured and the doses infused may well have led to supraphysiological plasma concentrations. ${ }^{34}$ Therefore the role of CCK as a physiological satiation factor in humans remains to be established.

In rats it has been shown that the CCK A receptor antagonist L-364,718 increased food intake during normal feeding ${ }^{117}$ and abolished the inhibition of feeding induced by either the intragastric administration of a protease inhibitor (Foy-305,200 mg/kg) or diversion of biliary pancreatic secretions, both of which result in a significant increase in plasma concentrations of CCK. ${ }^{35}$ Also in other animal studies there is evidence for a physiological satiation effect of CCK. ${ }^{891627}$ If endogenous CCK is a physiological satiation factor in humans than the blockade of the CCK receptors with the potent CCK A receptor antagonist loxiglumide would result in reversal of this satiation.

Drewe $e t$ al have shown that in humans an intraduodenal infusion of $36 \mathrm{~g} \mathrm{lipid} / \mathrm{h}$ induced a significant satiation compared with saline ${ }^{36}$ This satiation effect could not be blocked by loxiglumide. This high dose of lipid given intraduodenally, however, may have induced satiation factors that are much stronger than the CCK effect. In dogs it has been shown that jejunal infusions of more than $1.5 \mathrm{kcal} / \mathrm{min}$ induce considerable inhibition of motility and vomiting and retrograde contractions occurred when infusion was continued during complete inhibition. ${ }^{37}$ With energy loads smaller than $1.5 \mathrm{kcal} /$ min a typical motor pattern of the empty gut, so called phase III activity, recurred despite the 'digestive' state. ${ }^{37}$ Drewe et al have infused 4.9 $\mathrm{kcal} / \mathrm{min}$ intrajejunally and may therefore have disturbed small bowel motility and induced satiation.

This study was done to see if a low dose of intraduodenal fat induced satiety or satiation and if this effect could be blocked by a CCK receptor antagonist. We have chosen a very low dose of intraduodenal fat $(6 \mathrm{~g} / \mathrm{h}$ intralipid, corresponding to $0.9 \mathrm{kcal} / \mathrm{min}$ ) to avoid confounding effects 
on motility. In addition, we measured plasma CCK concentrations to see if the response to the low dose of intraduodenal fat was in the physiological postprandial range.

\section{Subjects and methods}

Ten healthy volunteers, with no diseases or previous surgery ( $5 \mathrm{M}, 5 \mathrm{~F}$, mean age 26) participated in this blind, randomised study. Informed consent was obtained from all subjects. The study was approved by the local ethics committee of the University of Leiden. For every experiment each subject presented, after an overnight fast, at 0800 at our research unit where a PVC Freka tube $\mathrm{CH} 8$ was introduced through one of the nostrils into the duodenum using a guide wire. After correct positioning as ascertained by fluoroscopy, the guide wire was removed and the tube fixed to the nose. The volunteers accustomed themselvers to the intraduodenal tube for one hour and at 0900 two intravenous catheters were placed into each forearm. From one catheter blood was drawn from $0915(t=-15)$ at 15 minutes intervals until the end of the study at 1300 for determination of plasma CCK. The other catheter was used for infusion from $0930(t=0)$ until $1300(t=210)$.

In a randomised blind investigation three experiments were done with at least one week interval (Table). At $0930(t=0)$ the intravenous infusion of saline (experiments $\mathrm{A}$ and $\mathrm{B}$ ) or loxiglumide $10 \mathrm{mg} / \mathrm{kg} / \mathrm{h}$ (experiment $\mathrm{C}$ ) was started. Loxiglumide (CR1505) a potent and specific CCK receptor antagonist ${ }^{38}$ was kindly provided by Rotta Research Laboratories (Monza, Italy). Sterilised and pyrogen free ampules containing $500 \mathrm{mg}$ of loxiglumide $(50 \mathrm{mg} / \mathrm{ml})$ were used for infusion after $1: 10$ dilution. At $\mathrm{t}=60$ the intraduodenal infusion consisting of saline (B) or intralipid $20 \%$ (KabiVitrum) $(30 \mathrm{ml} / \mathrm{h})$ was started. From $\mathrm{t}=60$ until the end of the infusion at $t=21015 \mathrm{~g}$ intralipid was infused into the duodenum.

At $1200(t=150)$ identical sandwiches with $10 \mathrm{~g}$ margarine and $15 \mathrm{~g}$ cheese $(3.33 \mathrm{kcal} / \mathrm{g})$ were served and the volunteers were invited to eat until they were fully satiated. The amount eaten was carefully measured as was the duration of the meal. They could drink mineral water (without carbon dioxide) as desired.

Basally and every 15 minutes hunger feelings, fullness feelings, prospective feeding intentions, and desire to eat were scored as subjective criteria on $100 \mathrm{~mm}$ visual analogue scales as described by Blundell and Silverstone. ${ }^{139}$

The subjects were also asked to fill in these hunger scores at home after after the experiment at $1400,1500,1600,1700$, and 1800 to assess satiety.

As described by Hill ${ }^{10}$ and modified to Dutch feeding customs, every 30 minutes from $t=0$ to

\begin{tabular}{lll} 
Experimental design of study & \\
\hline Experiment & Intravenous infusion & Intraduodenal infusion \\
\hline A & Saline & Fat (intralipid $20 \%, 6 \mathrm{~g} / \mathrm{h})$ \\
$\mathrm{B}$ & Saline & Saline \\
C & $(10 \mathrm{mg} / \mathrm{kg} / \mathrm{h})$ & Fat (intralipid $20 \%, 6 \mathrm{~g} / \mathrm{h})$ \\
& & \\
\hline
\end{tabular}

$\mathrm{t}=210 \mathrm{a}$ list and photograph of six protein rich, six fat rich, six carbohydrate rich items (each item on the photograph containing $200 \mathrm{kcal}$ ), and six low energy items was presented. From each of these 24 items the subjects were asked if they wanted to eat the amount shown, twice the amount, half the amount or nothing, independent of the other items. At each time interval the total amount of caloric items was calculated (half the amount $=1 / 2$ caloric item, double the amount is 2 caloric items). Also the amount of protein, fat, and carbohydrate items that the subjects wanted to eat was calculated independently.

Plasma CCK was determined in one run using a sensitive and specific radioimmunoassay as has previously been described. ${ }^{+1}$ The intra-assay variation was between $4 \cdot 6$ and $11 \cdot 5 \% .^{41}$

Results are expressed as mean (SEM). Statistical analysis of hunger feelings was performed by calculating the integrated area under the curve followed by Wilcoxon's test for paired results. These non-parametric tests were also used for the other comparisons.

\section{Results}

FOOD INTAKE

Food intake was $24 \%$ lower during low dose intraduodenal fat (206 (35) g) when compared with saline (269 (37) g), p=0.09). Loxiglumide partially prevented the decrease in food intake during intraduodenal fat to $9 \%(245(30) \mathrm{g}$ ) (Fig 1). The differences in food intake, however, did not reach statistical significance.

\section{HUNGER FEELINGS}

Before the intralipid infusion no differences in hunger feelings were seen. During the intralipid infusion there was a significant satiating effect compared with the control study $(p<0.05)$ according to the food selection lists (Fig 2).

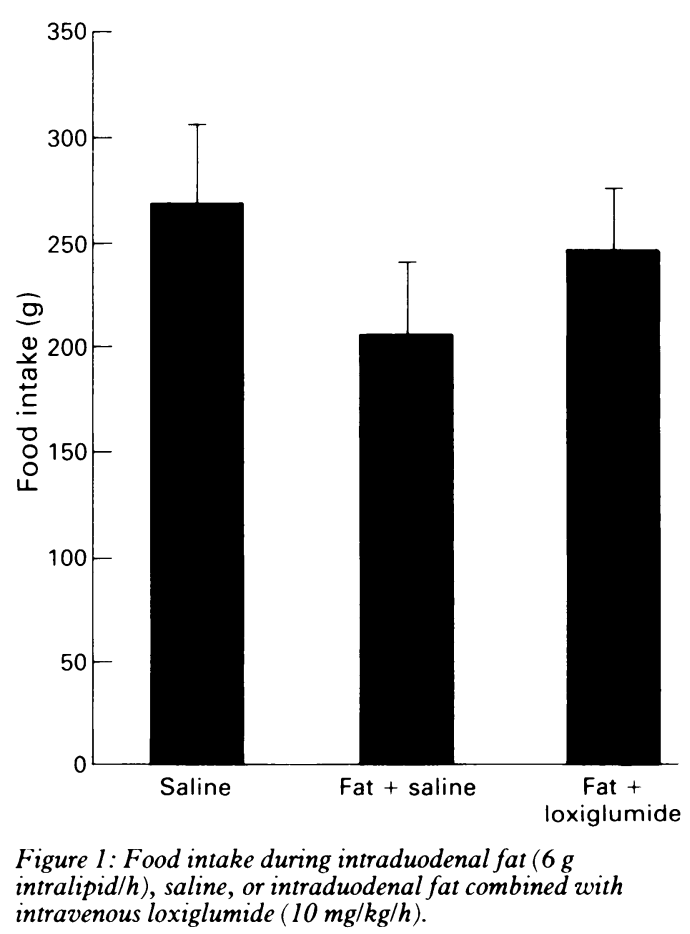



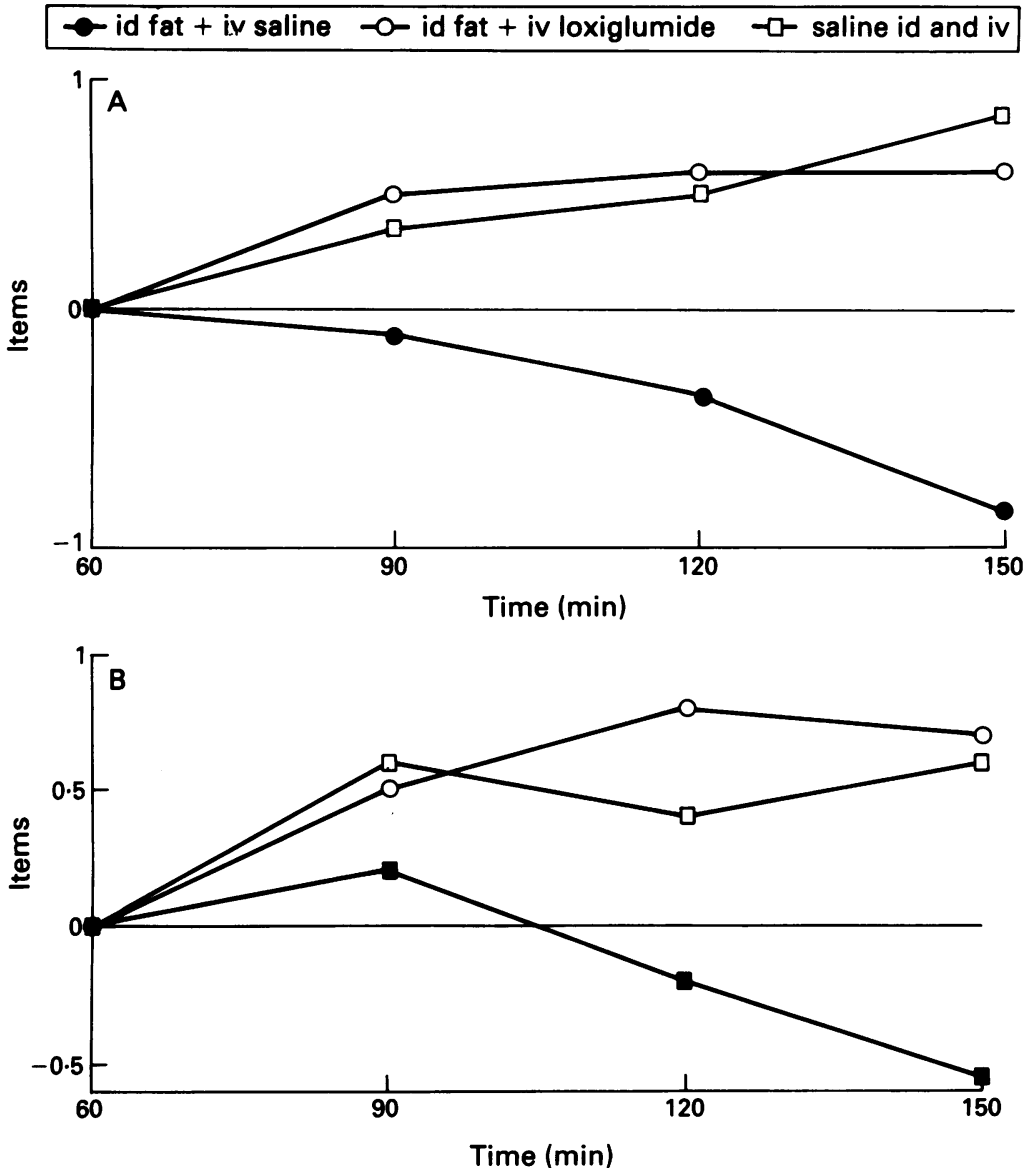

Figure 2: (A) Selection of caloric items during the intraduodenal (id) infusion period from $t=60$ until the meal at $t=150$. Values from $t=60$ are subtracted. Intraduodenal intralipid induced $a$ significant satiating effect $\mathrm{v}$ saline, which was reversed during loxiglumide $(p<0.05)$; $(B)$ Selection of fatty items during the intraduodenal (id) infusion period from $t=60$ until the meal at $t=150$. Values from $t=60$ are subtracted. Intraduodenal intralipid induced a significant satiating effect $\mathrm{v}$ saline, which was reversed during loxiglumide $(p<0.05)$. iv=Intravenous.
This satiating effect of intraduodenal fat was abolished by loxiglumide. If not all the caloric items but only the fatty items are analysed, intraduodenal fat (A) induced also a significant satiety effect compared with saline (B) or loxiglumide $(\mathrm{C})(\mathrm{p}<0.05$, Fig $2 \mathrm{~B})$. No significant differences were seen for the protein rich or carbohydrate rich items. For hunger feelings, desire to eat, fullness, and prospective feeding intentions no significant differences were found apart from an increase in fullness during intraduodenal fat compared with the control or loxiglumide experiments $(\mathrm{p}<0.05$, Fig 3). As Figure 3 shows there is also a trend for diminished hunger, desire to eat, and prospective feeding intentions during intraduodenal fat compared with the control and loxiglumide experiment but this did not reach significance when analysing the incremental area under the curve from 60 to 150 minutes. Analysing the period from 120 to 150 minutes separately, however, hunger and desire to eat were significantly lower during intralipid (A) compared with the control (B) or loxiglumide experiment $(C)$ $(p<0.05)$. When analysing the differences between $t=150$ (start of the meal) and $t=60$ minutes (start of the intralipid infusion) a significant difference in hunger desire to eat, prospective feeding and fullness was seen between the intralipid (A) and control experiment (B). With that method, however, no significant differences were seen between the intralipid (A) and loxiglumide (C) experiment although there was a tendency towards less satiety with loxiglumide. There were no differences in hunger feelings in the hours after the experiment. No adverse effects were reported during any test.

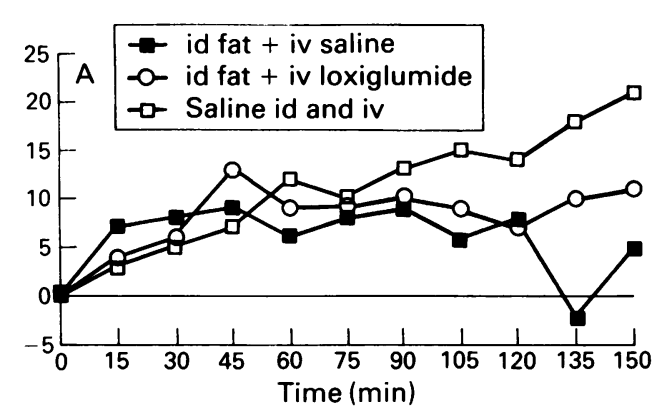

id infusion

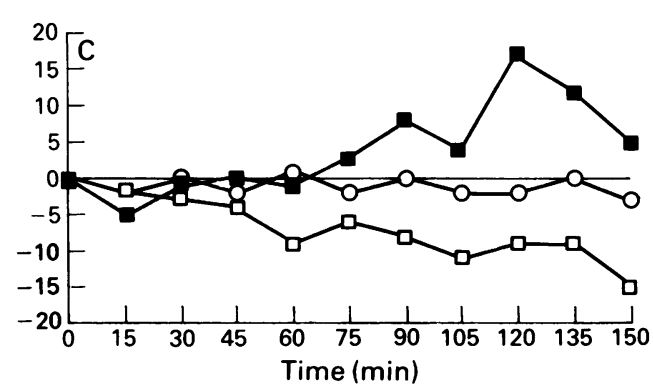

id infusion

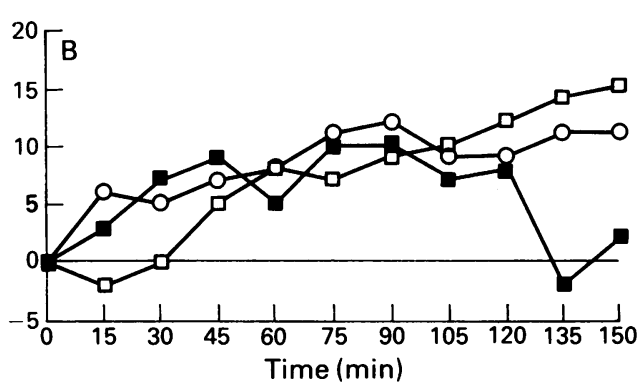

id infusion

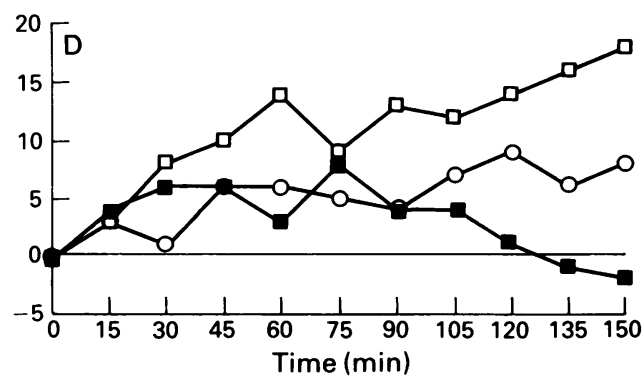

Figure 3: Hunger $(A)$, desire to eat $(B)$, fullness $(C)$, and prospective feeding intentions $(D)$. Intraduodenal (id) fat induced a significant increase in fullness $(p<0.05)$ before the meal compared with saline or intraduodenal fat combined with intravenous (iv) loxiglumide. 


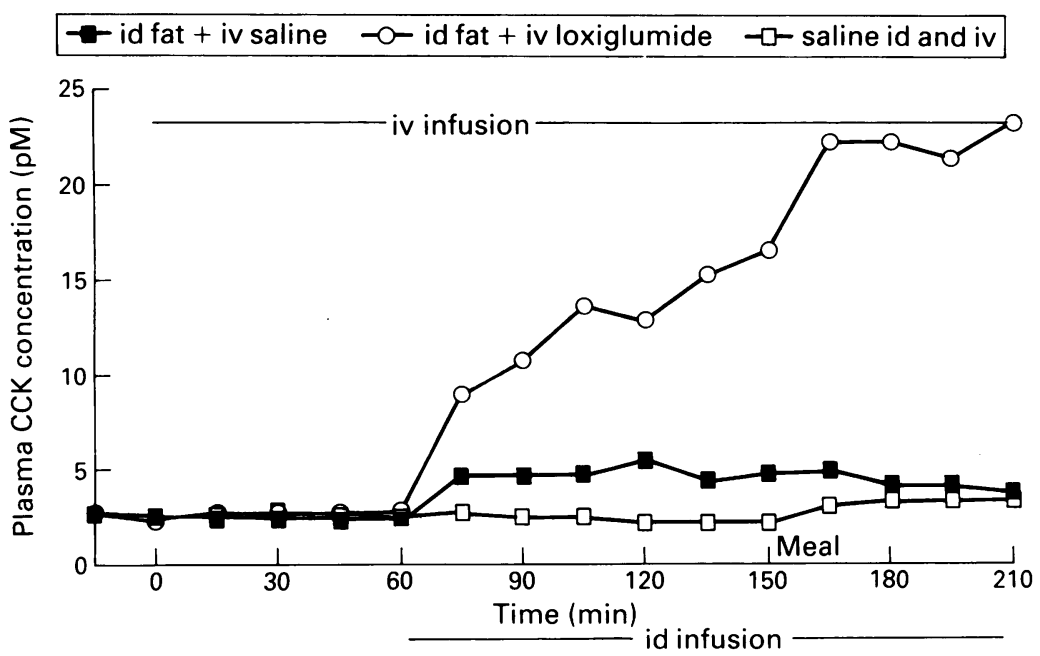

Figure 4: Plasma

cholecystokinin $(C C K)$ during intraduodenal (id) fat (6 $\mathrm{g}$ intralipid/h), saline or intraduodenal fat combined with intravenous (iv) loxiglumide $(10 \mathrm{mg} / \mathrm{kg} / \mathrm{h})$.

CCK

Mean basal plasma CCK was not significantly different during the three experiments (respectively $2 \cdot 6(0 \cdot 1), 2 \cdot 7(0 \cdot 3)$, and $2 \cdot 6(0 \cdot 2) \mathrm{pM}$ during experiments $A, B$, and $C)$. During the intraduodenal fat infusion there was a significant increase of plasma CCK from $2 \cdot 4(0.3$ at $\mathrm{t}=60 \mathrm{~min}$ to 4.8 $(0.4) \mathrm{pM}$ at $\mathrm{t}=150 \mathrm{~min}$ (start of meal, $\mathrm{p}<0.001$; Fig 4). In the loxiglumide experiment (C) this CCK release was exaggerated to $16 \cdot 5(2 \cdot 4) \mathrm{pM}$. After the meal there was a further increase in plasma CCK to $23 \cdot 2(1 \cdot 8)$ pM (Fig 4, p <0.01). In the control experiment plasma CCK was not changed until the meal was eaten.

\section{Discussion}

In rats, it has been shown that intraduodenal oleic acid induces CCK release and feeding depression whereas intraduodenal triolein does not induce CCK release or feeding depression. ${ }^{42} 43$ This finding suggests that fat affects feeding by releasing CCK. In our experiments we have shown that with an intraduodenal infusion of only $6 \mathrm{~g}$ intralipid/h we could induce a significant CCK increase leading to plasma concentrations previously found after a regular meal. ${ }^{3}$ This intraduodenal fat infusion induced a significant (subjective) satiety effect and caused a decrease in food intake of $24 \%$ compared with the control experiment. The specific CCK A receptor antagonist prevented this satiety effect and partially reversed the decrease in food intake. Loxiglumide alone did not have an effect on food intake in humans. ${ }^{44}$

The only other study on the effect of fat on plasma CCK and satiety used a much larger amount of fat. ${ }^{36}$ In that study Drewe et al have shown that an intraduodenal infusion of $36 \mathrm{~g}$ of $\mathrm{lipid} / \mathrm{h}$ induced a significant satiation compared with saline, which could not be blocked by loxiglumide. ${ }^{36}$ Greenberg et al have suggested that a paracine effect of endogenous CCK was not fully excluded, because it is unknown, if the dose of loxiglumide also completely blocks such a paracine stimulation. ${ }^{45} \mathrm{We}$ feel, however, that the very high amount of fat may have affected the results in Drewe's study. It may well be possible that a disturbed gastrointestinal motility after this high energy load may have overruled the satiety effect of CCK. ${ }^{37}$ In our study we have shown that a similar dose of loxiglumide did affect feeding parameters. In rats it has been shown that a CCK A receptor antagonist increased food intake during normal feeding ${ }^{10} 17$ and also blocked the inhibition of feeding by the intragastric administration of a proteinase inhibitor (Foy-305 $200 \mathrm{mg} / \mathrm{kg}$ ) or biliopancreatic diversion, both procedures inducing a significant increase in plasma concentrations of CCK. ${ }^{35}$ Peripheral (type A) CCK receptor antagonists reversed the inhibitory effects of CCK 8 on food intake in rats, but the central (B) CCK receptor antagonist L-365,260 did not. ${ }^{+647}$ Rats increased their food intake after type A but not after type B cholecystokinin receptor blockade. ${ }^{+8}$ In pigs the CCK A receptor antagonist L-364,718 also diminished the inhibition of feeding after intraduodenal infusion of fat emulsion and monoglyceride, but not after oleic acid, glycerol or glucose, suggesting the presence of CCK dependent (intraduodenal fat emulsion or monoglyceride) and CCK independent satiety mechanisms. ${ }^{7}$ In pigs L-364,718 also stimulated feeding by lever pressing. ${ }^{8}$ Also in animal studies there is ample evidence for a physiological satiation effect of CCK. ${ }^{9} 1627$

We have also now found in humans that endogenous CCK plays a key part in the decreased food intake and increased satiety when introduodenal fat is given. During a low dose of intraduodenal intralipid the subjects wanted to eat significantly less calories, especially fatty items, compared with saline. This selective effect of fat infusion on the choice of fat is important theoretically and practically because it points to a feedback mechanism from physiology (detection of fat) to behaviour (food selection). Blockade of CCK A receptors by loxiglumide abolished this satiating effect of intraduodenal fat. Also for fullness we observed the same pattern; increased satiety when CCK is released during intraduodenal intralipid, which is reversed by loxiglumide. The same pattern was seen for the other satiety parameters where loxiglumide decreased the satiety effects of intraduodenal intralipid.

The mechanism, whereby CCK influences feeding in humans, is unknown. It is suggested that in animals the mechanism whereby CCK induces satiety entails afferent gastric vagal neurons. ${ }^{49}$

CCK receptor blockade by loxiglumide did not influence hunger feelings during the 60 minute period before intraduodenal fat was given. This finding, suggesting that CCK does not participate in satiety in the fasting state, contrasts with a recent study by Wolkowich et $a l .{ }^{48}$ These authors found significantly increased hunger scores 90 minutes after the oral intake of $10 \mathrm{mg}$ of the specific CCK A receptor antagonist MK-329 (L-364,718) compared with placebo. ${ }^{50}$ The reason for this discrepancy is not evident. Differences, however, in study design and type, dose, and the method of administration of the CCK receptor antagonists may have played a part.

Loxiglumide did not influence basal plasma CCK concentrations but induced a considerable increase in plasma CCK after intraduodenal intralipid. This finding is in agreement with 
other studies where CCK receptor antagonists have been given. ${ }^{51}$ It is possible that this augmented CCK release during loxiglumide is partly explained by a diminished bile acid concentration in the lumen of the proximal small intestine because of diminished gall bladder emptying and partly by a diminished local release of somatostatin in the intestinal mucosa..$^{52}$

In conclusion, this study shows that in humans a low dose of intraduodenal fat increases satiety and satiation mainly through the effect of CCK.

1 Blundell JE, Burley VJ. Satiation, satiety and the action of fibre on food intake. Int $\mathcal{F}$ Obes 1987; 11: 9-25.

2 Blundell JE. Pharmacological approaches to appetite suppression. Trends Pharmacol Sci 1991; 12: 147-57.

3 Hopman WPM, Jansen JBMJ, Lambers CBHW. Comparative study of the effects of equal amounts of fat, protein and starch on plasma cholecystokinin in man. Scand $\mathcal{f}$ Gastrostarch on plasma cholecys
enterol $1985 ; 20: 843-7$.

4 Linden A. Role of cholecystokinin in feeding and lactation. Acta Physiol Scand Suppl 1989; 585: 1-49.

Gibbs J, Young RC, Smith GP. Cholecystokinin decreases food intake in rats. F Comp Physiol Psychol 1973; 84: 488-95.

6 Bado A, Rodriguez M, Lewin MJM, et al. Cholecystokinin suppresses food intake in cats: structure-activity characterization. Pharmacol Biochem Behav 1988; 31: 297-303.

7 Gregory PC, McFadyen M, Rayner DV. Duodenal infusion of fat, cholecystokinin secretion and satiety in the pig. Physiol Behav 1989; 45: 1021-4.

8 Ebenezer IS, De La Riva C, Baldwin BA. Effects of the CCK receptor antagonist MK-329 on food intake in pigs. Physiol Behav 1990; 47: 145-8.

9 Weller A, Smith GP, Gibbs J. Endogenous cholecystokinin reduces feeding in young rats. Science 1989; 247: 1589-91.

10 Hewson G, Leighton GE, Hill RG, Hughes J. The cholecystokinin receptor antagonist L 364,718 increases food cystokinin receptor antagonist $\mathrm{L} 364,718$ increases food intake in the rat by attenuation of the action of endo

11 McCoy JG, Stump F, Avery DD. Intake of individual macronutrients following ip injections of BBS and CCK in rats. Peptides 1990; 11: 221-5.

12 Della-Fera MA, Coleman BD, Baile CA. CNS injection of CCK in rats: effects on real and sham feeding and gastric emptying. Am $\mathcal{F}$ Physiol 1990; 258: R1165-9.

13 Gourch A, Orosco M, Rodriguez M, et al. Effects of a new cholecystokinin analogue (JMV236) on food intake and brain monoamines in the rat. Neuropeptides 1990; 15: 37-41.

14 Smith GP. The therapeutic potential of cholecystokinin. Int $\mathcal{F}$ Obes $1984 ; 8$ (suppl 1): 35-8.

15 Figlewicz DP, Sipols AJ, Porte D, et al. Intraventricular CCK inhibits food intake and gastric emptying in baboons. $A m \mathcal{F}$ Physiol 1989; 256: R1313-7.

16 Silver AJ, Flood J, Song AM, Morley JE. Evidence for a physiological role for CCK in the regulation of food intake in mice. Am f Physiol 1989; 256: R646-52.

17 Reidelberger RD, O'Rourke MF. Potent cholecystokinin antagonist $\mathrm{L} 364718$ stimulates food intake in rats. $\mathrm{Am} \mathcal{J}$ Physiol 1989; 257: R1512-8.

18 Inui A, Okita M, Inoue T, et al. Effect of cholecystokinin octapeptide analogues on food intake in the dog. Am Physiol 1989; 257: R949-51.

19 McHugh PR, Moran TH. The stomach, cholecystokinin and satiety. Fed Proc 1986; 45: 1384-90.

20 Baile CA, McLaughlin CL, Della-Fera MA. Role of cholecystokinin and opioid peptides in control of food intake. cystokinin and opioid peptides

21 Moran TH, McHugh PR. Gastric and nongastric mechanisms for satiety action of cholecystokinin. Am $\mathcal{F}$ Physiol 1988; 254 : R628-32.

22 West DB, Fey D, Woods SC. Cholecystokinin persistently suppresses meal size but not food intake in free-feeding rats. Am ₹ Physiol 1984; 246: R776-87.

23 McLaughlin CL, Baile CA. Decreased sensitivity of Zucker obese rats to the putative satiety agent cholecystokinin Physiol Behav 1980; 25: 543-8.

24 Le Sauter J, Geary N. Redundant vagal mediation of the synergistic satiety effect of pancreatic glucagon and cholecystokinin in sham feeding rats. F Auton Nero Syst 1990; 30 : 13-22.
25 McLaughlin CL, Peikin SR, Baile CA. Food intake response to modulation of secretion of cholecystokinin in Zucker rats. Am F Physiol 1983; 244: R676-85.

26 McLaughlin CL, Peikin SR, Baile CA. Trypsin inhibitor effects on food intake and weight gain in Zucker rats. Physio Behav 1983; 31: 487-91.

27 McLaughlin CL, Baile CA, Buonomo FC. Effect of CCK antibodies on food intake and weight gain in Zucker rats. Physiol Behav 1985; 34: 277-82.

28 McLaughlin CL, Baile CA. Feeding response of weanling Zucker obese rats to cholecystokinin and bombesin. Physiol Behav 1980; 25: 341-6.

29 Silver AJ, Morley JE. Role of CCK in regulation of food intake. Prog Neurobiol 1991; 36: 23-34

30 Stacher G. Effects of cholecystokinin and caerulein on human eating behavior and pain sensation: a review. Psychoneuroendocrinology 1986; 11: 39-48.

31 Pi-Sunyer X, Kissileff HR, Thornton J, Smith GP. CTerminal octapeptide of cholecystokinin decreases food intake in obese man. Physiol Behav 1982; 29: 627-30.

32 Kissileff HR, Pi-Sunyer X, Thornton J, Smith GP. C-terminal octapeptide of cholecystokinin decreases food intake in man. Am F Clin Nutr 1981; 34: 154-60.

33 Shaw MJ, Hughes JJ, Morley JE, Levine AS, Silvis SE, Shafer RB. Cholectystokinin octapeptide action on gastric emptying and food intake in normal and vagotomized man Ann NY Acad Sci 1985; 448: 640-1.

34 Reidelberger RD, Kalogeris TJ, Solomon TE. Plasma CCK levels after food intake and infusion of CCK analogues that levels after food intake and infusion of CCK analogues that

35 Garlicki J, Konturek PK, Majka J, Kwiecien N, Konturek SJ Cholecystokinin receptors and vagal nerves in control of food intake in rats. Am $\mathcal{F}$ Physiol 1990; 258: E40-5.

36 Drewe J, Gadient A, Rovati LC, Begliner C. Role of circulating cholecystokinin in control of fat-induced inhibition of food intake in humans. Gastroenterology 1992; 102: 1654-9.

37 Ehrlein HJ. Recording of intestinal motility is a useful contro of enteral nutrition. Clinical Nutrition 1992; 11 (suppl): 62.

38 Makovec F, Chrisé R, Barri M, Paccini MA, Setikas I, Rovati LA. New glutaramic acid derivatives with potent, competitive and specific cholecystokinin-antagonist activity. Arzmeimittelforschung 1985; 35: 1048-51.

39 Silverstone $B$. Measurement of hunger and food intake in man. In: Silverstone T, ed. Drugs and Appetite. London: man. In: Silverstone T, ed.

40 Hill AJ. Investigation of short term influence on hunger, satiety and food consumption. Leeds: Leeds University, 1987. (Thesis.)

41 Jansen JBMJ, Lamers CBHW. Radioimmunoassay of cholecystokinin in human tissue and plasma. Clin Chim Acto 1983; 131: 305-16.

42 Greenberg D, Smith GP, Gibbs J. Intraduodenal infusions of ats elicit satiety in sham-feeding rats. Am f Physiol 1990 259: R110-8.

43 Lewis LD, Williams JA. Regulation of cholecystokinin (CCK) secretion [Abstract]. FASEB F 1989; 3: 997.

44 Lieverse RJ, Jansen JBMJ, Zwan A van der, Samson L Masclee AAM, Rovati CC, et al. Bombesin reduces food intake in lean man by a cholecystokinin-independent mechanism. I Clin Endocrinol Metab 1993; 76: 1495-8.

45 Greenberg D, Smith GP, Gibbs J. Cholecystokinin and the satiating effect of fat. Gastroenterology 1992; 102: 1801-3.

46 Smith GP, Tyrka A, Gibbs J. Type-A CCK receptors mediate the inhibition of food intake and activity by CCK-8 in 9- to 12-day-old rat pups. Pharmacol Biochem Behav 1991; 38: 207-10.

47 Dourish CT, Ruckert AC, Tattersall FD, Iversen SD. Evidence that decreased feeding induced by systemic injection of cholecystokinin is mediated by CCK-A receptors. Eur F Pharmacol 1989; 173: 233-4.

48 Corwin RL, Gibbs J, Smith GP. Increased food intake after type A but not type B cholecystokinin receptor blockade. Physiol Behav 1991; 50: 255-8.

49 Lieverse RJ, Jansen JBM J, Lamers CBHW. Cholecystokinin and satiation. Neth $\mathcal{F}$ Med 1993; 42: 146-52.

50 Wolkowitz OM, Gertz B, Weingartner $H$, Beccaria L, Thompson $\mathrm{K}$, Liddle RA. Hunger in humans induced by MK-329, a specific peripheral-type cholecystokinin receptor antagonist. Biol Psychiatry 1990; 28: 169-73.

51 Jansen JMBJ, Jebbink MCW, Douglas BR, Lamers CBHW Effect of loxiglumide (CR1505) on bombesin and meal stimulated plasma cholecystokinin release in man. Eur Clin Pharmacol 1990; 28: 367-70.

52 Jebbink MCW. Regulation of secretion and actions of cholecystokinin in man. Studies with the cholecystokininreceptor antagonist loxiglumide. Leiden University, Dordrecht: ICG Publishers, 1992. (Thesis.) 